\title{
SIFAT FISIK TANAH PADA BERBAGAI JARAK DARI SALURAN APLIKASI LIMBAH CAIR PABRIK KELAPA SAWIT
}

\section{The Soil Physical Characteristic on Various Distances from Canal Application of Waste of Palm Oil Factory Liquid}

\author{
Friska Anggreani Silalahi, Nelvia \\ Jurusan Agroteknologi Fakultas Pertanian Universitas Riau \\ Email: friskaanggreani.silalahi@yahoo.com (082388841103) \\ [Diterima: Desember 2016 ; Disetujui: Maret 2017]
}

\begin{abstract}
This research aimed to study the effect of the application of waste of palm oil factory liquid on the soil physical characteristic of palm oil plantations. The application of waste of palm oil factory liquid done on a tract the application of which is called by the land application (LA) and LA have been made over 8 years. The research conducted inland of palm oil plantation Batubara Regency, North Sumatra Province from August to November 2015. The method used in this research was survey method. Determination of the sampling and research location was done deliberately by the purpose of the research (purposive sampling). Soil samples for analysis of soil physical characteristic were taken from distance 1,2, 3, 4, and 5 meters from canal application of palm oil factory liquid waste or land application (LA) with $0-10 \mathrm{~cm}, 10-20 \mathrm{~cm}$ and 20-30 cm depth each other taken from 5 points, included two on the right and left upper of LA and two on the right and left downstream of LA, and without LA used as a control. The results showed that the application of waste of palm oil factory liquid to decreases bulk density and increase the total pore space, water content, permeability and C-organic of soil of oil palm plantations compared to control at a distance 1 meter from LA and decreased with the farther the distance LA $(5 \mathrm{~m})$ and deeper $(0-30 \mathrm{~cm})$, but will not affect particles density.
\end{abstract}

Keywords: Waste of palm oil factory liquid, Soil physical characteristic

\begin{abstract}
ABSTRAK
Penelitian ini bertujuan untuk mempelajari pengaruh penerapan limbah cair pabrik kelapa sawit terhadap karakteristik fisik tanah perkebunan kelapa sawit. Penerapan limbah cair pabrik kelapa sawit dilakukan pada saluran yang aplikasinya disebut dengan aplikasi tanah (LA), dan LA telah dibuat selama 8 tahun. Penelitian dilakukan di pedalaman perkebunan kelapa sawit Kabupaten Batubara, Provinsi Sumatera Utara dari Agustus hingga November 2015. Metode yang digunakan dalam penelitian ini adalah metode survei. Penentuan lokasi pengambilan sampel dan penelitian dilakukan dengan sengaja sesuai dengan tujuan penelitian (purposive sampling). Sampel tanah untuk analisis karakteristik fisik tanah diambil dari jarak 1,2, 3, 4, dan 5 meter dari aplikasi kanal limbah cair pabrik kelapa sawit atau aplikasi tanah (LA) dengan 0-10 cm, 10-20 cm dan $20-30 \mathrm{~cm}$ kedalaman satu sama lain diambil dari 5 poin, termasuk dua di kanan dan kiri atas LA dan dua di kanan dan kiri hilir LA, dan tanpa LA digunakan sebagai kontrol. Hasil penelitian menunjukkan bahwa penerapan limbah cair pabrik kelapa sawit untuk mengurangi kepadatan curah dan meningkatkan total ruang pori, kadar air, permeabilitas dan C-organik tanah perkebunan kelapa sawit dibandingkan dengan kontrol pada jarak 1 meter dari LA dan menurun dengan semakin jauh jarak LA $(5 \mathrm{~m})$ dan lebih dalam $(0-30 \mathrm{~cm})$, tetapi tidak akan mempengaruhi kepadatan partikel.
\end{abstract}

Kata kunci : Limbah cair pabrik kelapa sawit, Karakteristik fisik tanah 


\section{PENDAHULUAN}

Pengembangan tanaman kelapa sawit di Indonesia sangat besar, hal tersebut dapat dilihat dari perluasan areal tanaman kelapa sawit yang sangat signifikan di Indonesia. Pada tahun 2014 terjadi peningkatan luas areal perkebunan kelapa sawit yaitu pada tahun 2010 luas areal 8.385.394 ha menjadi 10.965.231 ha pada tahun 2014. (Ditjenbun, 2014).

Pabrik pengolahan kelapa sawit (PPKS) juga mengalami peningkatan seiring dengan peningkatan luas areal perkebunan kelapa sawit. Pemanfaatan pabrik pengolahan kelapa sawit berdampak pada peningkatan produksi Crude Palm Oil (CPO) dan hasil samping berupa limbah padat dan limbah cair. Limbah cair setiap hari dihasilkan dalam jumlah besar. Lubis dan Tobing (1989) mengatakan bahwa setiap 1 ton CPO dari TBS menghasilkan limbah cair sebanyak 5 ton.

Limbah cair pabrik kelapa sawit (LCPKS) sebagai hasil samping mempunyai potensi cukup besar untuk dimanfaatkan sebagai bahan pembenah tanah pada lahan kelapa sawit. Limbah cair pabrik kelapa sawit mengandung bahan organik yang tinggi, serta mengandung unsur hara makro seperti $\mathrm{N}, \mathrm{P}$ dan $\mathrm{K}$ yang dibutuhkan oleh tanaman. Menurut Atmaja et al,. (2005) limbah cair pabrik kelapa sawit sebanyak $1 \mathrm{~m}^{3}$ setara dengan $1,5 \mathrm{~kg}$ Urea, 0,3 kg SP-36, dan 1,2 kg Kiserit. Limbah cair dapat dimanfaatkan ke areal tanaman kelapa sawit dengan sistem land application.

Land application atau aplikasi lahan adalah pemanfaatan limbah cair sebagai pupuk atau bahan penyubur tanah bagi tanaman kelapa sawit itu sendiri. Bahan organik yang terdapat dalam limbah cair pabrik kelapa sawit dapat memperbaiki sifat-sifat tanah dan pertumbuhan kelapa sawit (Atmaja et al., 2005).

Pemanfaatan limbah cair pabrik kelapa sawit dengan metode land application dapat meningkatkan sifat kimia, biologi dan fisika tanah. Salah satunya adalah perubahan terhadap sifat fisik tanah seperti kemantapan agregat tanah, total ruang pori tanah dan permeabilitas, yang dapat mempengaruhi struktur tanah, aerasi tanah, gerak air tanah dan daya serap tanah. Dengan demikian, penerapan land application akan mempengaruhi sifat fisik tanah pada jarak tertentu dari saluran aplikasi limbah cair pabrik kelapa sawit.
Hasil penelitian Ketaren (2010) menunjukkan bahwa pemberian limbah cair pabrik kelapa sawit berpengaruh nyata dalam meningkatkan C-Organik tanah, meskipun demikian pemberian limbah cair dapat menurunkan bobot isi, meningkatkan total ruang pori tanah, dan meningkatkan laju permeabilitas tanah.

Menurut hasil penelitian Chaniago (2009) lahan yang diaplikasikan limbah cair PKS pada tahun 2008 memiliki sifat fisik tanah masing-masingnya menunjukkan kandungan bahan organik, ketersediaan air tanahtotal ruang pori berturut-turut $1,39,6,15$, dan $60,15 \%$, berat volume tanah $1,04 \mathrm{~g} / \mathrm{cm}^{3}$, permeabilitas 3,39 $\mathrm{cm} / \mathrm{jam}$, memiliki tekstur lempung, dan dominan warna gelap, yang lebih baik dari aplikasi tahun 2007 diantaranya kandungan bahan organik ketersediaan air tanah, total ruang pori berturut-turut $0,9,3,54$, dan $57,12 \%$, berat volume tanah $1,13 \mathrm{~g} / \mathrm{cm}^{3}$, dan permeabilitas 2,69 cm/jam.

Tujuan dari penelitian ini adalah untuk mempelajari pengaruh aplikasi limbah cair pabrik kelapa sawit terhadap sifat fisik tanah perkebunan kelapa sawit.

\section{BAHAN DAN METODE}

Sampel tanah untuk penelitian diambil pada lahan kelapa sawit yang terletak di Kabupaten Batubara, Provinsi Sumatera Utara, sedangkan analisis sifat fisik tanah dilakukan di Laboratorium Tanah, Fakultas Pertanian, Universitas Riau, Kampus Bina Widya, Pekanbaru. Penelitian berlangsung dari bulan Agustus sampai November 2015.

Bahan yang digunakan antara lainbahan kimia dan peralatan yang digunakan berupa ring, bor belgi, cangkul, parang, meteran, pisau, ayakan $50 \mu \mathrm{m}$, pipet $20 \mathrm{ml}$, permeameter, timbangan analitik, gelas piala, cawan nikel, elenmeyer, pipet tetes, stopwatch, oven, alat tulis, dan peralatan lainnya untuk analisis tanah di laboratorium.

Penelitian dilakukan dalam bentuk survei. Penetapan lokasi penelitian dan pengambilan sampel dilakukan dengan sengaja sesuai dengan tujuan penelitian (purposive sampling). Pengambilan sampel tanah dilakukan di daerah dengan jenis tanah ultisol, 
kemiringan lahan $1 \%$, umur tanaman kelapa sawit 18 tahun, lama land aplikasi 8 tahun, lebar land aplikasi 1,5 $\mathrm{m}$, dan proses pengendapan berkisar satu tahun atau hingga berubah ke bentuk padat. Sampel tanah untuk analisis sifat fisika tanah diambil pada jarak 1 , 2, 3, 4, dan 5 meter dari saluran aplikasi limbah cair pabrik kelapa sawit (land application) dengan kedalaman 0-10 cm, 10-20 cm, dan 20$30 \mathrm{~cm}$ masing-masing diambil pada 5 titik, yaitu 2 dikanan dan kiri hulu serta 2 dikanan dan kiri hilir, dan tanpa land application digunakan sebagai kontrol.

Parameter yang diamati meliputi kadar air, bobot isi, kerapatan partikel partikel, total ruang pori, permeabilitas, dan C-organik tanah. Hasil analisis setiap parameter dianalisis secara deskriptif.

\section{HASIL DAN PEMBAHASAN}

\section{Kandungan C-organik dan Sifat Fisik Tanah Ultisol Tanpa AplikasiLCPKS}

Kandungan C-organik dan sifat fisik tanah ultisol tanpa aplikasi LCPKS disajikan pada Tabel 1.
Tabel 1 menunjukkan bahwa tekstur pada tanah lokasi penelitian adalah lempung liat berpasir, yaitu termasuk tanah dengan tekstur sedang tetapi agak halus. Menurut Hakim et al., (1986) bahwa lempung liat, lempung liat berpasir atau lempung liat berdebu termasuk tanah bertekstur sedang tetapi agak halus. Kandungan pasir yang tinggi pada tanah ultisol yaitu sebesar $66,89 \%$ dimana tanah-tanah dengan kandungan pasir yang tinggi memiliki butiran-butiran berukuran lebih besar, sehingga setiap satuan berat (misalnya setiap gram) mempunyai luas permukaan yang lebih kecil sehingga sulit menyerap (menahan) air dan unsur hara. Hal ini sesuai dengan pendapat Hardjowigeno (2002) bahwa tanah-tanah pasir mempunyai daya menahan air yang kecil.

C-organik tergolong sangat rendah yaitu $0,72 \%$, karena tanah ultisol biasanya terdapat pada daerah yang memiliki suhu rendah dan curah hujan tinggi sehingga dekomposisi bahan organik rendah dan pencucian serta erosi tinggi. Menurut Harjowigeno (2003) bahwa tanah ultisol merupakan tanah yang miskin unsur hara terutama kandungan bahan organik dan mempunyai kadar bahan organik yang rendah $(<1 \%)$.

$\underline{\text { Tabel 1. Kandungan C-organik dan sifat fisik tanah ultisol tanpa aplikasi LCPKS }}$

\begin{tabular}{|c|c|c|c|c|c|}
\hline \multirow{2}{*}{$\begin{array}{l}\text { C-organik dan sifat } \\
\text { fisik tanah } \\
\end{array}$} & \multicolumn{4}{|c|}{ kedalaman $(\mathrm{cm})$} & \multirow[b]{2}{*}{ Keterangan } \\
\hline & $0-30$ & $0-10$ & $10-20$ & $20-30$ & \\
\hline pasir $(\%)$ & 66,89 & - & - & - & \multirow{3}{*}{$\begin{array}{l}\text { Lempung liat } \\
\text { berpasir }\end{array}$} \\
\hline debu $(\%)$ & 8,99 & - & - & - & \\
\hline liat (\%) & 24 & - & - & - & \\
\hline C-organik (\%) & 0,72 & & & & \\
\hline $\mathrm{BD}\left(\mathrm{g} / \mathrm{cm}^{3}\right)$ & - & $1,19^{\mathrm{s}}$ & $1,12^{\mathrm{s}}$ & $1,08^{\mathrm{s}}$ & \\
\hline $\mathrm{PD}\left(\mathrm{g} / \mathrm{cm}^{3}\right)$ & - & 2 & 2,12 & 2,15 & \\
\hline $\operatorname{TRP}(\%)$ & - & $40,50^{\mathrm{kb}}$ & $47,17^{\mathrm{kb}}$ & $49,77^{\mathrm{kb}}$ & \\
\hline $\mathrm{KA}(\%)$ & - & 21,4 & 19,6 & 19,3 & \\
\hline Permeabilitas $(\mathrm{cm} / \mathrm{jam})$ & - & $0,89^{\text {al }}$ & $1,14^{\mathrm{al}}$ & $1,82^{\mathrm{al}}$ & \\
\hline
\end{tabular}

Bulk density pada setiap kedalaman tergolong kriteria sedang, hal ini dipengaruhi oleh C-organik yang sangat rendah sehingga bulk density menjadi tinggi. Menurut Sutedjo (2002) faktor yang mempengaruhi bulk density salah satunya adalah bahan organik tanah, dimana tanah dengan kandungan bahan organik rendah akan memiliki bulk density tinggi begitupula sebaliknya. Bahan organik memperkecil bulk density tanah, karena bahan 
organik jauh lebih ringan dari pada mineral (Hardjowigeno,2003).

Particle density yang tertinggi terdapat pada kedalaman $20-30 \mathrm{~cm}$, tetapi tidak begitu berbeda pada setiap kedalaman. Berat ukuran dan cara teraturnya partikel-partikel tanah, tidak berpengaruh terhadap particle density, akan tetapi kandungan bahan organik akan memberi pengaruh yang besar terhadap partikel density sehingga pada awalnya tanah yang ada pada bagian atas mempunyai nilai lebih rendah dibandingkan dengan tanah lapisan bawah (Hakim et al., 1986).

Total ruang poritanah memiliki perbedaan yang tidak besar disetiap kedalaman yang termasuk kedalam kriteria kurang baik, hal ini terlihat pada tekstur yang didapat adalah lempung liat berpasir, dimana kandungan pasirnya tinggi. Menurut Hardjowigeno (2003) porositas tanah dipengaruhi oleh salah satunya adalah tekstur tanah, dimana tekstur tanah mengandung lebih banyak pasir. Jumlah ruang pori sebagian ditentukan oleh susunan butirbutir padat, apabila letak keduanya cenderung erat, seperti pada pasir atau subsoil yang padat, total porositasnya rendah (Buckman dan Brady, 1984).

Hasil analisis kadar air pada kedalama 0$10 \mathrm{~cm}$ adalah yang lebih tinggi dibandingkan dengan kedalaman 10-30 cm. Hal ini diduga karena penelitian dilakukan saat musim penghujan jumlah air dari curah hujan umumnya lebih tinggi dari pada jumlah air yang dievapotranspirasikan sehingga kadar air didalam lapisan tanah cenderung menurun. Menurut Harjowigeno (2007) menyatakan bahwa kadar air dalam tanah tergantung pada banyaknya curah hujan, kemampuan tanah menahan air, besarnya evapotranspirasi, dan kandungan bahan organik.

Permeabiltas tanah yang tertinggi terdapat pada kedalaman 20-30 cm. Pada kedalaman $\quad 0-10 \quad \mathrm{~cm}$ sampai 20-30 $\mathrm{cm}$ permeabilitas tergolong kriteria agak lambat. Bulk density mempengaruhi permeabilitas tanah, dimana semakin dalam kedalaman maka bulk density semakin menurun, sedangkan pada permeabilitas tanah semakin dalam kedalaman permeabilitas tanah meningkat. Hal ini sesuai dengan pendapat Yulnafatmawita et al,. (2010) bahwa penurunan bobot isi tanah mengakibatkan peningkatan laju permeabilitas tanah.
Pengamatan hasil analisis secara keseluruhan pada tanah ultisol dengan tanpa aplikasi LCPKS memperlihatkan bahwa perbedaan nilai kadar air, bulk density, particle density, total ruang pori dan permeabiltas tanah berdasarkan kedalaman tanah, antara kedalaman 0-10 cm dengan 10-20 cm dan kedalam $20-30 \mathrm{~cm}$ tidak begitu besar, hal ini disebabkan tidak adanya pemberian limbah LCPKS pada tanah tersebut. Hal ini menunjukkan bahwa tanah tersebut mempunyai kesuburan fisik rendah.

\section{Sifat Fisik Tanah Ultisol Lahan Perkebunan Kelapa Sawit yang diaplikasiLCPKS}

Sifat fisik tanah yaitu, bobot isi, kerapatan partikel, total ruang pori, kadar air, permeabilitas, dan C-organik tanah disajikan pada Tabel 2, Tabel 3, Tabel 4, Tabel 5, Tabel 6, dan Tabel 7.

\section{Bobot Isi Tanah (Bulk density)}

Tabel 2 menunjukkan bahwa bobot isi tanah pada kedalaman 0-10, 10-20 dan 20-30 $\mathrm{cm}$ cenderung meningkat dari jarak $1 \mathrm{~m}$ sampai ke jarak $5 \mathrm{~m}$, namun masih dalam kriteria sedang untuk jarak $1 \mathrm{~m}$ sampai jarak $4 \mathrm{~m}$. Sedangkan pada kedalaman 10-20 dan 20-30 dengan jarak saluran $5 \mathrm{~m}$ tergolong kriteria tinggi dibandingkan tanpa aplikasi LCPKS yang tergolong sedang. Hal ini didukung oleh hasil penelitian Sakiah dan Batubara (2014) bahwa aplikasi limbah cair pabrik kelapa sawit meningkatkan bulk density tanah, yaitu dengan jarak $60 \mathrm{~cm}$ dari parit aplikasi memiliki bulk density $2,57 \mathrm{~g} / \mathrm{cm}^{3}$, sedangkan pada jarak 120 $\mathrm{cm}$ dari parit aplikasi bulk density $2,64 \mathrm{~g} / \mathrm{cm}^{3}$.

Aplikasi LCPKS cenderung menurunkan bobot isi tanah dibandingkan dengan tanpa aplikasi LCPKS. Hal ini diperkuat oleh hasil penelitian Chaniago (2009) bahwa lahan yang diaplikasikan limbah cair PKS menurunkan berat volume tanah, yaitu aplikasi tahun 2007 memiliki berat volume $1,13 \mathrm{~g} / \mathrm{cm}^{3}$, sedangkan aplikasi tahun 2008 memiliki berat volume 1,04 $\mathrm{g} / \mathrm{cm}^{3}$. 
Tabel 2. Bulk density tanah ultisol lahan perkebunan kelapa sawit yang diaplikasi LCPKS

\begin{tabular}{clll}
\hline Jarak dari saluran aplikasi & \multicolumn{3}{c}{ Bulk density $\left(\mathrm{g} / \mathrm{cm}^{3}\right)$} \\
\cline { 2 - 4 } LCPKS & $0-10 \mathrm{~cm}$ & $10-20 \mathrm{~cm}$ & $20-30 \mathrm{~cm}$ \\
\hline $1 \mathrm{~m}$ & $0,92^{\mathrm{s}}$ & $0,99^{\mathrm{s}}$ & $1,07^{\mathrm{s}}$ \\
$2 \mathrm{~m}$ & $0,96^{\mathrm{s}}$ & $1,02^{\mathrm{s}}$ & $1,11^{\mathrm{s}}$ \\
$3 \mathrm{~m}$ & $0,97^{\mathrm{s}}$ & $1,09^{\mathrm{s}}$ & $1,13^{\mathrm{s}}$ \\
$4 \mathrm{~m}$ & $1,06^{\mathrm{s}}$ & $1,12^{\mathrm{s}}$ & $1,15^{\mathrm{s}}$ \\
$5 \mathrm{~m}$ & $1,18^{\mathrm{s}}$ & $1,26^{\mathrm{s}}$ & $1,37^{\mathrm{t}}$ \\
\hline
\end{tabular}

$\mathrm{s}=$ sedang, $\mathrm{t}=$ tinggi

Bulk density sangat berhubungan erat dengan particle density (Tabel 3) jika particle density tanah sangat besar maka bulk density juga besar, hal ini dikarenakan particle density berbanding lurus dengan bulk density, namun apabila sebuah tanah memilki tingkat kadar air yang tinggi maka particle density dan bulk density akan rendah hal ini dikarenakan particle density berbanding terbalik dengan kadar air (Hanafiah, 2004).

Bahan organik tanah semakin meningkat dengan semakin jauh jarak saluran aplikasi LCPKS (Tabel 7) yang akan menyebabkan bulk density menurun. Bahan organik tanah berperan sebagai perekat (pengikat) partikel tanah sehingga agregasi tanah menjadi naik, ruang pori tanah meningkat dan bulk density menurun. Menurut Wiskandar (2002) bahwa penambahan bahan organik akan meningkatkan total ruang pori tanah dan akan menurunkan bulk density. Hal ini sesuai dengan pernyataan Thamrin (2000) dalam Mariana(2006) bahwa bahan organik bersifat porus, ketika ke dalam tanah akan menciptakan ruang pori di dalam tanah sehingga bulk density tanah menjadi turun.

Hardjowigeno (1989) menyatakan salah satu kegunaan menentukan bulk density adalah evaluasi terhadap kemungkinan akar menembus tanah dengan bulk density yang turun biasanya pori-pori tanah makin banyak terbentuk. Semakin padat suatu tanah semakin tinggi bulk density, yang berarti semakin sulit menembus akar tanaman. Pada umumnya bulk density tanah mineral berkisar antara $1,1-1,6 \mathrm{~g} / \mathrm{cm}^{3}$.

\section{Kerapatan Partikel Tanah (Particle Density)}

Tabel 3 menunjukkan bahwa particle density tidak berpengaruh oleh aplikasi LCPKS di setiap kedalaman 0-10 cm, 10-20 cm dan 20$30 \mathrm{~cm}$ dan jarak $1 \mathrm{~m}, 2 \mathrm{~m}, 3 \mathrm{~m}, 4 \mathrm{~m}$, dan $5 \mathrm{~m}$ dari saluran aplikasi LCPKS dengan nilai yang tidak begitu berbeda, begitu pula tanpa aplikasi LCPKS.

Tabel 3. Particle density tanah ultisol lahan perkebunan kelapa sawit yang diaplikasi LCPKS

\begin{tabular}{clll}
\hline Jarak dari saluran aplikasi & \multicolumn{3}{c}{ Particle Density $\left(\mathrm{g} / \mathrm{cm}^{3}\right)$} \\
\cline { 2 - 4 } LCPKS & $0-10 \mathrm{~cm}$ & $10-20 \mathrm{~cm}$ & $20-30 \mathrm{~cm}$ \\
\hline $1 \mathrm{~m}$ & 2,13 & 2,13 & 2,15 \\
$2 \mathrm{~m}$ & 2,16 & 2,18 & 2,22 \\
$3 \mathrm{~m}$ & 2,16 & 2,21 & 2,23 \\
$4 \mathrm{~m}$ & 2,22 & 2,22 & 2,23 \\
$5 \mathrm{~m}$ & 2,22 & 2,26 & 2,31 \\
\hline
\end{tabular}

Kandungan bahan organik didalam tanah sangat mempengaruhi kerapatan butir tanah akibatnya tanah permukaan biasanya kerapatan butirnya lebih kecil dari subsoil.. Meskipun demikian kerapatan butir tanah tidak banyak berbeda (Madjid, 2010).

LCPKS mengandung bahan organik (Tabel 7) yang mana bahan organik dapat mempengaruhi kerapatan partikel tanah (particle density). Semakin tinggi bahan organik tanah, maka kerapatan partikel tanah semakin rendah.

Hillel (1982) menyatakan bahwa dengan adanya bahan organik akan memperkecil kerapatan partikel tanah. Beberapa faktor yang mempengaruhi particle density tanah, diantaranya yaitu tekstur, bahan organik, struktur, bulk density dan topongrafi. Bahan organik komposisinya di dalam tanah memang sedikit yaitu berkisar 3-5\% tapi pengaruhnya sangat besar terhadap perubahan sifat-sifat 
tanah. Tekstur tanah dapat diartikan sebagai penampilan visual suatu tanah berdasarkan komposisi kualitatif dari ukuran butiran tanah dalam suatu massa tanah tertentu. Tekstur tanah menunjukkan komposisi partikel penyusun tanah (Hanafiah, 2004).

Kepadatan partikel setiap tanah merupakan suatu tetapan dan tidak bervariasi menurut jumlah ruang partikel. Hal ini didefinisikan sebagai massa setiap unit volume partikel tanah dan kerap kali dinyatakan dalam gram $/ \mathrm{cm}^{3}$. Untuk kebanyakan tanah mineral kerapatan partikelnya rata-rata sekitar 2,6 $\mathrm{gr} / \mathrm{cm}^{3}$. Hal ini tidak berbeda banyak pada tanah yang berbeda pula. Jika tidak akan terdapat suatu variasi yang harus mempertimbangkan kandungan tanah organik atau komposisi mineral (Foth, 1989).

\section{Total Ruang Pori Tanah}

Tabel 4 menunjukkan bahwa semakin jauh jarak dari aplikasi LCPKS dengan kedalaman 0-10 cm, $10-20 \mathrm{~cm}$, dan $20-30 \mathrm{~cm}$, maka total ruang pori tanah semakin menurun. Pada kedalaman 0-10 dan 10-20 cm dengan jarak 1-3 m tergolong kriteria baik, sedangkan pada kedalaman 20-30 cm dengan jarak 1-4 m total ruang pori tergolong kurang baik. Total ruang pori yang terendah terdapat pada kedalaman 20-30 cm dengan jarak $5 \mathrm{~cm}$ tergolong kriteria jelek.

Tabel 4. Total ruang poritanah ultisol lahan perkebunan kelapa sawit yang diaplikasi LCPKS

\begin{tabular}{clll}
\hline Jarak dari saluran & \multicolumn{3}{c}{ Total Ruang Pori (\%) } \\
\cline { 2 - 4 } aplikasi LCPKS & $0-10 \mathrm{~cm}$ & $10-20 \mathrm{~cm}$ & $20-30 \mathrm{~cm}$ \\
\hline $1 \mathrm{~m}$ & $57,14^{\mathrm{b}}$ & $53,59^{\mathrm{b}}$ & $49,46^{\mathrm{kb}}$ \\
$2 \mathrm{~m}$ & $56,58^{\mathrm{b}}$ & $53,06^{\mathrm{b}}$ & $48,52^{\mathrm{kb}}$ \\
$3 \mathrm{~m}$ & $56,23^{\mathrm{b}}$ & $50,68^{\mathrm{b}}$ & $47,48^{\mathrm{kb}}$ \\
$4 \mathrm{~m}$ & $52,32^{\mathrm{b}}$ & $49,21^{\mathrm{kb}}$ & $47,97^{\mathrm{kb}}$ \\
$5 \mathrm{~m}$ & $48,92^{\mathrm{kb}}$ & $43,93^{\mathrm{kb}}$ & $38,29^{\mathrm{j}}$ \\
\hline
\end{tabular}

Ket: $b=$ baik, $k b=$ kurang baik, $j=$ jelek

Aplikasi LCPKS cenderung meningkatkan total ruang pori tanah pada setiap jarak (1-5 $\mathrm{m})$ dibanding tanpa aplikasi LCPKS. Hal ini diperkuat oleh hasil penelitian Chaniago (2009) bahwa lahan yang diaplikasikan limbah cair PKS meningkatkan total ruang pori tanah, yaitu aplikasi tahun 2007 memiliki total ruang pori $57,12 \%$, sedangkan aplikasi tahun 2008 memiliki total ruang pori $60,15 \%$.

Penurunan total ruang pori akan menyebabkan peningkatan bulk density. Menurut Soepardi (1983) bahwa semakin tinggi bulk density tanah, maka total ruang pori semakin rendah. Pernyataan ini sama dengan pendapat Sarief (1989) bahwa penurunan ketahanan penetrasi tanah disebabkan oleh menurunnya bobot isi tanah dan meningkatnya pori tanah, sedangkan peningkatan ketahanan penetrasi tanah disebabkan oleh meningkatnya bobot isi tanah dan menurunnya pori tanah, sehingga menurunkan pori aerase dan permeabilitas tanah.
Hardjowigeno (2003), bahwa porositas dipengaruhi oleh bahan organik. Makin tinggi bahan organik maka semakin rendah bobot volume tanah dan semakin tinggi total ruang pori tanah. Limbah cair pabrik kelapa sawit yang memiliki banyak kandungan bahan organik (Tabel 7), sehingga total ruang pori tanah dapat meningkat.

Bahan organik juga meningkatkan aktivitas mikroorganisme di dalam tanah, dimana mikroorganisme tanah ini mempengaruhi terhadap peningkatan porositas total melalui proses mineralisasi (Rao, 1982). Sesuai dengan hasil penelitian Tarigan (2000) selain dari dalam tanah mikroorganisme ini juga berasal dari mikroorganisme perombak limbah yang digunakan untuk pengolahan LCPKS, dimana kuantitatif mikroba semakin meningkat dengan pemberian endapan limbah.

\section{Kadar Air Tanah}

Tabel 5 menunjukkan bahwa kadar air pada kedalaman 0-10 $\mathrm{cm}$ semakin rendah 
dengan semakin jauh dari saluran LCPKS yaitu dari $1 \mathrm{~m}$ ke $5 \mathrm{~m}$. Sedangkan kadar air pada kedalaman 10-20 dan 20-30 $\mathrm{cm}$ dengan jarak $1 \mathrm{~m}, 2 \mathrm{~m}, 3 \mathrm{~m}, 4 \mathrm{~m}$, dan $5 \mathrm{~m}$ cenderung lebih tinggi. Aplikasi LCPKS dapat meningkatkan kadar air dibanding tanpa aplikasi LCPKS.

Tabel 5. Kadar air tanah ultisol lahan perkebunan kelapa sawit yang diaplikasi LCPKS

\begin{tabular}{clll}
\hline Jarak dari saluran aplikasi & \multicolumn{3}{c}{ Kadar Air $(\%)$} \\
\cline { 2 - 4 } LCPKS & $0-10 \mathrm{~cm}$ & $10-20 \mathrm{~cm}$ & $20-30 \mathrm{~cm}$ \\
\hline $1 \mathrm{~m}$ & 29,07 & 29,75 & 29,80 \\
$2 \mathrm{~m}$ & 28,45 & 29,57 & 29,62 \\
$3 \mathrm{~m}$ & 27,27 & 27,57 & 27,95 \\
$4 \mathrm{~m}$ & 25,40 & 26,62 & 27,47 \\
$5 \mathrm{~m}$ & 22,10 & 26,12 & 26,55 \\
\hline
\end{tabular}

Kadar air tanah dipengaruhi oleh kadar bahan organik tanah dan kedalaman solum, semakin tinggi kadar bahan organik tanah akan semakin tinggi kadar air, serta semakin dalam kedalaman solum tanah maka kadar air juga semakin tinggi (Hanafiah, 2010).

Hasil pengamatan menunjukkan bahwa LCPKS mengandung bahan organik, dimana bahan organik tanah dapat memperbaiki sifat-sifat fisik tanah salah satunya memperbaiki laju pergerakan air dan total ruang pori yang saling berkaitan atau berbanding lurus. Pernyataan ini sesuai dengan hasil penelitian Nurmegawati (2011) bahwa tingginya total ruang pori tanah maka akan semakin banyak air yang lolos ke bawah dan rendahnya total ruang pori tanah maka lalu lintas air jadi terhambat. Harahap (2007) berpendapat bahwa semakin banyak akar atau perkembangan akar semakin giat, maka laju infiltrasi juga semakin meningkat dan hal ini sejalan dengan peningkatan persentase pori-pori tanah.

Total ruang pori tanah yang tinggi dan bobot isi tanah yang rendah juga mempengaruhi kadar air kapasitas lapang. Menurut Islami dan Utomo (1995) bahwa jika tanah mempunyai nilai bobot isi yang rendah dan total ruang pori tinggi berarti tanah tersebut longgar, sehingga air mudah masuk kedalam tanah akibatnya kadar air tanah menjadi lebih tinggi. Scholes et al,. (1994) dalam Atmojo (2003) menyatakan bahwa kadar air yang optimal bagi tanaman dan kehidupan mikroorganisme adalah sekitar kapasitas lapang.

\section{PermeabilitasTanah}

Tabel 6 menunjukkan bahwa Semakin tinggi tingkat kedalaman tanah dan jauh jarak pengambilan titik sampel dari LCPKS maka nilai permeabilitas semakin menurun. Permeabilitas tertinggi terdapat pada kedalaman 0-10 dengan jarak 1 meter. Permeabilitas pada kedalaman $10-20 \mathrm{~cm}$ dengan semakin jauh jarak maka permeabilitas semakin meningkat, tetapi masih dalam kriteria sedang.

Aplikasi LCPKS meningkatkan permeabilitas tanah dibanding tanpa aplikasi LCPKS. Hal ini diperkuat oleh hasil penelitian Chaniago (2009) bahwa lahan yang diaplikasikan limbah cair PKS meningkatkan permeabilitas tanah, yaitu aplikasi tahun 2007 memiliki permeabilitas $2,69 \mathrm{~cm} / \mathrm{jam}$, sedangkan aplikasi tahun 2008 memiliki permeabilitas $3,39 \mathrm{~cm} / \mathrm{jam}$.

Tabel 6. Permeabilitas tanah ultisol lahan perkebunan kelapa sawit yang diaplikasi LCPKS

\begin{tabular}{clll}
\hline Jarak dari saluran & \multicolumn{3}{c}{ Permeabilitas $(\mathrm{cm} /$ jam $)$} \\
\cline { 2 - 4 } aplikasi LCPKS & $0-10 \mathrm{~cm}$ & $10-20 \mathrm{~cm}$ & $20-30 \mathrm{~cm}$ \\
\hline $1 \mathrm{~m}$ & $6,92^{\mathrm{ac}}$ & $2,88^{\mathrm{s}}$ & $2,26^{\mathrm{s}}$ \\
$2 \mathrm{~m}$ & $6,09^{\mathrm{s}}$ & $2,69^{\mathrm{s}}$ & $2,28^{\mathrm{s}}$ \\
$3 \mathrm{~m}$ & $5,87^{\mathrm{s}}$ & $2,45^{\mathrm{s}}$ & $2,25^{\mathrm{s}}$ \\
$4 \mathrm{~m}$ & $5,65^{\mathrm{s}}$ & $3,93^{\mathrm{s}}$ & $1,99^{\mathrm{al}}$ \\
$5 \mathrm{~m}$ & $5,60^{\mathrm{s}}$ & $3,90^{\mathrm{s}}$ & $1,86^{\mathrm{al}}$ \\
\hline
\end{tabular}

Ket: ac = agak cepat, $\mathrm{s}=$ sedang, al = agak lambat 
Aplikasi LCPKS pada jarak lebih dekat dan kedalaman 0-10 cm memberikan hasil permeabilitas yang lebih tinggi dibandingkan dengan jarak lebih jauh dan kedalaman 20-30 $\mathrm{cm}$.

Aplikasi LCPKS berpengaruh terhadap permeabiltas tanah, hal ini dapat dilihat dari hasil pengamatan di atas dan data BD (Tabel 2) dimana bulk density tanah dan total ruang pori tanah mempengaruhi ketahanan penetrasi tanah dan permeabilitas tanah. Permeabilitas tanah memiliki lapisan atas dan bawah. Lapisan atas berkisar antara lambat sampai agak cepat $(0,20$ 9,46 cm/jam), sedangkan di lapisan bawah tergolong agak lambat sampai sedang $(1,10$ $3,62 \mathrm{~cm} / \mathrm{jam}$ ) (Suharta dan Prasetyo, 2008).

Total ruang pori (Tabel 3) tanah dapat mempengaruhi permeabilitas tanah, dimana semakin tinggi total ruang pori tanah maka permeabilitas semakin cepat. Hal ini sesuai dengan pandapat Hanafiah (2010) bahwa pori sangat menentukan sekali dalam permeabilitas tanah, semakin besar pori dalam tanah tersebut, maka semakin cepat pula permeabilitas tanah tersebut.
Dapat diketahui bahwa tanah dengan pori-pori yang kecil (halus) memiliki kemampuan untuk menahan air dalam tanah.

\section{C-Organik Tanah}

Tabel 7 menunjukkan bahwa C-organik tanah pada hulu saluran lebih tinggi dibandingkan dengan hilir saluran, dan semakin jauh jarak dari saluran aplikasi LCPKS kadar C-organik makin rendah. Terjadinya penurunan kandungan C-organik disebabkan bahan organik melalui pemberian limbah cair kelapa sawit telah mengalami dekomposisi. Seperti dinyatakan oleh Hakim et al,. (1986) bahwa dalam proses dekomposisi bahan organik menghasilkan senyawa yang lebih sederhana, $\mathrm{CO}_{2}$ dan $\mathrm{H}_{2} \mathrm{O}$. Proses dekomposisi tersebut dapat menurunkan kandungan bahan organik tanah.

Peningkataana C-organik tanah pada hulu saluran aplikasi LCPKS disebabkan oleh akumulasi bahan organik yang terdapat dalam LCPKS pada bagian hulu dan semakin jauh dari saluran lebih besar dibanding bagian hilir.

Tabel 7. C-organik tanah ultisol lahan perkebunan kelapa sawit yang diaplikasi LCPKS

\begin{tabular}{ccc}
\hline Jarak dari saluran & \multicolumn{2}{c}{ C - organik (\%) } \\
\cline { 2 - 3 } apliksi LCPKS & Hulu saluran & Hilir saluran \\
\hline $1 \mathrm{~m}$ & 1,44 & 0,76 \\
$2 \mathrm{~m}$ & 1,39 & 0,75 \\
$3 \mathrm{~m}$ & 1,03 & 0,71 \\
$4 \mathrm{~m}$ & 0,94 & 0,71 \\
$5 \mathrm{~m}$ & 0,74 & 0,65 \\
\hline
\end{tabular}

Peningkatan C-organik tanah akibat aplikasi LCPKS disebabkan adanya kandungan bahan organik terlarut dan padat yang berasal dari LCPKS (Agustin et al., 2008). Hal ini diperkuat oleh hasil penelitian Chaniago (2009) bahwa lahan yang diaplikasikan limbah cair PKS pada tahun 2007 memiliki kandungan bahan organik $0,94 \%$ meningkat menjadi kandungan bahan organik 1,39\%. pada aplikasi tahun 2008.

Anas (2000) menyatakan bahwa bahan organik mengandung kadar karbon (C) dapat mencapai sekitar 48\%-58\% dari berat total bahan organik. Apabila bahan organik telah mengalami dekomposisi maka akan dihasilkan sejumlah senyawa karbon seperti $\mathrm{CO}_{2}, \mathrm{CO}_{3}^{-2}$, $\mathrm{HCO}_{3}{ }^{-}, \mathrm{CH}_{4}$, dan C. Diantara senyawa karbon yang sederhana tersebut, $\mathrm{CO}_{2}$ adalah yang paling banyak. Lebih lanjut dijelaskan bahwa karbondioksida dan metan akan digunakan oleh bakteri fotosintetik dan merubahnya menjadi substrat yang bermanfaat dan apabila bakteri fontosintetik tersebut mati dan kemudian melapuk akan menghasilkan karbon organik dalam tanah.

\section{KESIMPULAN}

Berdasarkan penelitian yang telah dilakukan dapat diambil kesimpulan bahwa aplikasi limbah cair pabrik kelapa sawit menurunkan berat volume dan meningkatkan total ruang pori, kadar air, permeabilitas, serta C-organik tanah perkebunan kelapa sawit 
dibanding kontrol pada jarak 1 meter dari saluran LA dan menurun dengan semakin jauh jarak LA $(5 \mathrm{~m})$ dan semakin dalam $(0-30 \mathrm{~cm})$, tetapi tidak berpengaruh terhadap partikel density.

\section{DAFTAR PUSTAKA}

Agustin, M B, Sengpracha W P and Phutdhawong. 2008. Electrocoagulation of palm oil mill effluent. International Journal of Environmental Research and Public Health. Volume 5 (3) 177-80.

Anas,L. 2000. Potensi Sampah Kota untuk Pertanian Di Indonesia dalam Seminar dan Lokakarya Pengelolaan Sampah Organik Untuk Mendukung Program Ketahanan Pangan dan Kelestarian Lahan Pertanian. Kongres MAPORINA, 6-7 September 2000, Malang. Hal. 1-11.

Atmaja, A. W., K. E. S. Manik dan A. Niswati. 2005. Pengaruh Pemberian Limbah Cair Pengolahan Minyak Kelapa Sawit Terhadap Populasi Cacing Tanah dan Jumlah Keanekaragaman Fauna Tanah di PTPN VII Lampung. Phttp://www.unila.ac.id. Diakses pada tanggal 22 Januari 2015.

Atmojo, S. W. 2003. Peranan Bahan Organik Terhadap Kesuburan Tanah dan Upaya Pengelolaannya. Sebelas Maret University Press. Surakarta.

Buckman, H.O. dan N. C. Brady. 1984. Ilmu Tanah. Bhatara Karya Aksara.

Chaniago, A. 2009. Pengaruh lama aplikasi limbah cair pabrik kelapa sawit PT. Amal plantation terhadap beberapa sifat fisika tanah di desa Tapian Kandis kecamatan Palembayan kabupaten Agam. Skripsi Fakultas Pertanian Universitas Andalas, Padang. (Tidak dipublikasikan).

Direktorat Jendral Perkebunan. 2014. Statistik Perkebunan Indonesia 2010-2013 Kelapa Sawit. $\quad$ www.ditjenbun.deptan.go.id. Diakses pada tanggal 28 Fabruari 2015.

Foth, H. D., 1989. Dasar-Dasar Ilmu Tanah. Gajah Mada University Press. Yogyakarta.

Hardjowigeno, S. 1989. Ilmu Tanah. Mediyatama Sarana Perkasa Jakarta

Hardjowigeno, S. 2002. Ilmu Tanah. Akademika Pressinda. Jakarta
Hardjowigeno, S. 2003. Klasifikasi Tanah dan Pedogenesis. Jakarta. Akademika Pressindo.

Hardjowigeno, S. 2007. Ilmu Tanah. Akademika Pressindo. Jakarta

Hakim, N., M.Y. Nyakpa, A.M. Lubis, S.G. Nugroho, M.A. Diha, Go Ban Hong dan H.H Bailey. 1986. Dasar-Dasar Ilmu Tanah. Universitas Lampung.

Hanafiah, K.A. 2004.Dasar-Dasar Ilmu Tanah.PT. Raja Grafindo Persada. Jakarta.

Hanafiah, K.A. 2010.Dasar-Dasar Ilmu Tanah.PT. Raja Grafindo Persada. Jakarta.

Harahap, E. M. 2007. Peranan Tanaman Kelapa Sawit pada Konservasi Tanah dan Air.Universitas Sumatera Utara. Medan.

Hillel, D. 1982. Introduction to Soil Physics. Academic Press Inc, Orlando, Florida.

Islami, T dan Utomo. 1995. Hubungan Tanah, Air dan Tanaman. IKIP Semarang Press.

Ketaren, E.F. 2010. Evaluasi sifat fisik, pH, dan C-organik tanah akibat aplikasi limbah cair pabrik kelapa sawit di PT. Smart Padang Halaban Kabupaten Labuhan Batu Utara. Skripsi Fakultas Pertanian Universitas Sumatera Utara, Medan. (Tidak dipublikasikan).

Loebis, B. dan P. L. Tobing. 1989. Potensi pemanfaatan limbah pabrik kelapa sawit. Buletin Perkebunan. Pusat Penelitian Perkebunan Kelapa Sawit. Medan. 20 (1): 49-56.

Madjid. 2010. Sifat dan Ciri Tanah. Fakultas Pertanian Institut Pertanian Bogor. Bogor.

Mariana, H. 2006. Pengaruh Kompos Ampas Tapioka dan Pemberian Air terhadap Ketersediaan Air dan Peetumbuhan Tanaman Sawi ( Brassica juncea L.) pada Entisol Wajak, Malang. Skripsi Jurusan Tanah, Fakultas Peratanian Universitas Brawijaya. Malang.

Nurmegawati. 2011. Infiltrasi Pada Hutan di Sub Das Sumani Bagian Hulu Kayu Aro Kabupaten Solok. Jurnal Hidrolitan, Vol $2: 2: 87-95$.

Rao, S. 1982. Advances in Agricultural Microbiology Oxford\& IBH. Publishing Co. new Delhi, Bombay, Calcutta. Page 295-324. 
Sakiah dan A. A. Batubara. 2014. Pengaruh aplikasi limbah cair pabrik kelapa sawit terhadap beberapa sifat fisik tanah perkebunan kelapa sawit (elaeis guineensis Jacq.) di kebun Aek Nabara Selatan PT. Perkebunan Nusantara III. Jurnal Penelitian STIPAP. Volume 5 (2) : 39-60.

Sarief, E. S. 1989. Konservasi Air dan Tanah. Pustaka Buana. Bandung.

Soepardi G. 1983. Sifat dan Ciri Tanah.Bogor : Departemen Ilmu-Ilmu Tanah.

Suharta, M., dan Prasetyo E., 2008. Susunan Mineral dan Sifat Fisik - kimia Tanah. Balai Besar Penelitian dan Pengembangan Sumber Daya Lahan Pertanian. Bogor.

Sutedjo, M. M. dan A. G. Kartasapoetra. 2002. Pengantar Ilmu Tanah. Cetakan Ketiga. Rineka Cipta. Jakarta

Tarigan, F. M. 2000. Pengendalian limbahcair pabrik kelapa sawit secara biologis dan pengaruhnya terhadap sifat tanah, pertumbuhan tanaman kedelai (Glicine max) pada tanah ultisol. Tesis programpascasarjana. Universitas Sumatera Utara Medan.

Wiskandar. 2002. Pemanfaatan pupuk kandang untuk memperbaiki sifat fisik tanah di lahan keritis yang telah di teras. Kongres Nasional VII.

Yulnafatmawita, Saidi, A., Gusnidar, Adrinal, dan Suyoko. 2010. Peranan Bahan Hijauan Tanaman dalam Peningkatan Bahan Organik dan Stabilitas Aggregat Tanah Ultisol Limau Manisyang ditanami Jagung (Zea mays L.). Jurnal Solum Vol. VII No. 1 Januari 2010 : 37-48. 